\title{
Influence of Autocratic Leadership Style on the Job Performance of Academic Librarians in Benue State
}

\author{
Philip Usman Akor \\ Department of Library and Information Technology \\ Federal University of Technology, Minna, Nigeria
}

Doi:10.5901/jesr.2014.v4n7p148

\begin{abstract}
The major purpose of this study was to determine the influence of autocratic leadership style on the job performance of academic librarians in higher institutions of learning in Benue State of Nigeria. In carrying out this study 3 research questions were posed. The entire population which consisted of all the 87 librarians: this include 9 librarian managers in the 9 higher institutions of learning in Benue State. Two sets of data collection instruments which include: Autocratic leadership style questionnaire $\{A L S Q$ ) and the Job Performance of Academic Librarians Questionnaire (JPALQ) were used. The major findings of the study showed that the Librarian Managers in Benue State adopted more of democratic leadership style. This is followed by the bureaucratic leadership style then laissez-faire leadership style and lastly autocratic leadership style. Autocratic leadership style does not significantly influence the job performance of academic librarians. The level of performance of the academic librarians was low. Based on the above findings, it was recommended that librarian managers should be supervised and closely monitored by the institutions' management to ensure that autocratic and laissez-faire ones among them are checked. The institutions' management should through seminars and workshops encourage the usage of democratic leadership style in the administration of academic libraries in Benue State.
\end{abstract}

Keywords: Autocratic leadership style, job performance, academic librarians, Benue State.

\section{Introduction}

The approach the librarian managers adopt in directing, guiding and controlling the staff under them determine the pace of progress in their libraries. That is if the librarian managers control, direct or guide the staff under them properly by adopting ideal leadership style, staff will show greater commitment to their duty. But unfortunately some librarian managers are no longer effective and committed to their duties. Staff on their part become nonchalant about library work which invariably have negative impact on their job performance. According to Adamaechi and Romaine (2002) leadership is very essential in any kind of group or organisation and it can mean the difference between success or failure of any group or joint activity. Hence for enterprise to achieve its goals the leadership position of such enterprise must be occupied by competent leaders.

Leadership as a concept has been defined by so many writers Ngoka (2002) defined it as the process of influencing others towards organisational performance and achievement of goals. According to Igbo (2002) leadership is a process of influencing group activity towards achievement. It is the behaviour of an individual when he is directing and guiding the activities of the group towards a common goal. His success or failure in attaining the goals of the organisation depends largely on his ability to effectively organise and manipulate the human and material resources available to him. This in turn depends on his leadership styles.

Scholl (2000) refers to leadership style as the pattern of behaviour use by a leader in attempting to influence group members and make decision regarding the mission strategy and operation of group activities. Clark (2000) perceived leadership style as the manner and approach of providing direction, implementing plans and motivating people. Ukeje, Akabogu and Ndu (1992) opined that job performance has to do with the employees strength and weaknesses in his effort to accomplish task. Rhode (1989) defined job performance as an act of performing a job either well or badly.

Librarian managers should ensure effective leadership style that will lead to maximum job performance. Ram (2001), Mgbodile (2004), Melling and Little (2004) described autocratic, democratic and laissez-faire leadership styles extensively. According to them an autocratic leader is a leader who is high-handed in his administration. He is a centre of all the activities that go on in the establishment where he is a leader. A prime determinant of action, all authority emanated from him and ends with him. 
He monopolizes the decision-making process and takes decisions all alone. He believes his ideas and thoughts to be superior to those of his subordinates and considers involving them in decision-making as a waste of time. The interest and welfare of the worker is not taken into consideration as the leader regards him just as a mere tool for production. As part of his non-consideration for worker's welfare he resorts to commands, harsh and abusive language to induce compliance. He uses threats and intimidation as a means of ensuring absolute obedience and dependence on him. He does not take opposition kindly as he tends to regard those with opposing views as enemies of his administration. He clamps down on opposition with some ruthlessness and strives for conformity of all to his directives.

Workers under an autocratic leader may be seen as working under pressure and fear most of the time and often show dissatisfaction to this form of leadership by various means such as indulging in eye service, lateness to work, reduction of work output, sabotaging the work, seeking transfer or voluntarily resigning from the establishment. The autocratic leader finds it difficult to get genuine love, support and cooperation from subordinates who regard his administration as a "one man show' According to Yalokwu (2000), Canadian Association of Student Activity Advisers (2004) and Umeakuka (2005) an autocratic leader has little or no trust and faith in his or her subordinates; takes decision alone; gives order and command without considering the subordinates; determines group policy; gives step by step directions and dictates task; believes he is always right and entertains no question from subordinates. He may be subjective in evaluating members of his or her organisation and disregards the right of his or her subordinates. They added that an autocratic leader demands absolute obedience from the group not minding whether or not the group understands his or her principle. An autocratic leader believes he is the most qualified and knows the best answer to organisational problems. He relies on threat and punishment to influence the employees.

Nwankwo (2001) and Enoch (1999) described autocratic style as a leadership style in which production is emphasized at the expense of any human consideration, and where decision are made exclusively by the leader. The leader believes that human beings are evil, weak, unwilling to work, incapable of self-determination, and have limited reasoning. Therefore they must be directed, pushed and forced to do work. The summary of the characteristics of an autocratic leader as presented by Edem (1998) is as follows:

i. The dictation of all policies and procedures by the leader with little or no group participation in decisionmaking.

ii. The imposition of task and methods on the subordinates.

iii. An absence of communication between the leader and the group.

iv. Nagging and suspicion breeding on the part of the leader.

An autocratic style according to Pagewise (2002) is effective and should be used when new untrained employees who do not know which tasks to perform or which procedures to follow, effective supervision can be provided only through detailed orders and instruction and employees do not respond to any other leadership style. The Canadian Association of Student Activity Advisers (2004) also opined that autocratic leadership is effective and should be used when time is limited.

Canadian Association of Student Activity Advisers (2004) posited that autocratic style should not be used when developing a strong sense of team work is the goal, there is some degree of skill or knowledge in members, and when the group wants an element of spontaneity in their work.

The researcher opined that an autocratic leadership style is generally characterized by a decided performance for centralized decision-making power in the leader and reluctance to share position, power and authority with others. Tasks are assigned without consultation and the leader expects acceptance without questioning. The tone of the Library is full of pretence, fear and strictness to law and order.

In academic libraries in Benue State, one should reasonably assume that the leadership styles of the librarian managers will have a direct impact on the productivity of academic librarians under them. But the researcher's interview with some academic librarians at the Federal University of Agriculture, Makurdi, Benue State University, Makurdi, University of Mkar, College of Education, Oju and the Benue State Polytechnic, Ugbokolo showed a general prevailing climate characterised by tension. The researcher was worried about the non-application of motivational leadership techniques to make academic librarians perform their duties efficiently. The incessant open clashes and lack of cooperation between the academic librarians and the librarian managers are very glaring. The researcher therefore became interested in this topic in order to make an in-depth study on the extent autocratic leadership style influence job performance of academic librarians in Benue State of Nigeria. 


\subsection{Objectives of the Study}

The general purpose of this study was to determine the influence of autocratic leadership style on the job performance of academic librarians in Benue State of Nigeria.

Specifically the study was designed to:

- Identify the leadership styles exhibited by Librarian managers in academic libraries in Benue State.

- Find out the level of performance of academic librarians in Benue State.

- Ascertain the influence of autocratic leadership style on the job performance of academic librarians in Benue State.

\subsection{Research Questions}

1. What are the leadership styles exhibited by the librarian managers in Benue State?

2. What is the level of performance in the academic librarians in Benue State?

3. What is the influence of autocratic leadership style on the job performance of academic librarians in Benue State?

\section{Methodology}

The descriptive research design method was used to carry out this study. The independent variable "autocratic leadership style" which was involved in the study, was not manipulated or controlled directly by the researcher. According to Nworgu (2006) the group of items to which the study relates (I .e the population) may be small enough to warrant the inclusion of all of them in the study. Based on this, no sampling of this population was carried out. The entire population was therefore used because of the smallness of the population size. The population of this study consisted of all the 87 academic librarians (including 9 Librarian Managers) in the 9 higher institutions of learning in Benue State. The instrument used for collecting data for this study was questionnaire. Questionnaire was used for collecting data for this study because Jones (2006) is of the view that "the questionnaire is widely used and it is a useful instrument for collecting information providing structured, often numerical data, being able to administer without the presence of the researcher and often comparatively straight forward to analyse. The instrument was face-validated before use by presenting it to three senior colleagues in the field of library and information science. These experts were requested to examine the clarity of expression used as well as the appropriateness of language. The researcher administered and collected the questionnaire from the respondents. Thus there was a 100\% rate of returns of copies of the questionnaire distributed. The data for the study were presented in tables and analysed using mean and standard deviation.

\section{Findings, Analysis And Discussion}

Out of the 87 copies of the questionnaire that were administered to the academic librarians, 87 (100\%) were retrieved. The data from the retrieved questionnaire are hereby presented using simple statistics like mean and standard deviation.

Table 1: Mean of mean scores and SD of responses on leadership styles

\begin{tabular}{|c|l|c|c|}
\hline S/No. & Leadership Styles & Mean of mean & SD \\
\hline 1. & Autocratic leadership style & 2.46 & 0.30 \\
\hline 2. & Democratic leadership style & 2.90 & 0.33 \\
\hline 3. & Bureaucratic leadership style & 2.63 & 0.31 \\
\hline 4. & Laissez-fair leadership style & 2.62 & 0.31 \\
\hline
\end{tabular}

Table1 above shows the mean scores of leadership styles of librarianmanagers in Benue State of Nigeria. A democratic leadership style has the highest mean of mean score of 2.90. This is followed by the bureaucratic style with the mean of mean score of 2.63. Laissez-fair leadership has a mean of mean score of 2.62 and lastly followed by the autocratic style of leadership with the mean of mean score of 2.46.this shows that the four leadership styles are utilised by the librarian managers at varying levels. 
Table 2:

\begin{tabular}{|c|c|c|c|c|}
\hline S/NO & Level of performance of the Academic Librarians & $\mathrm{N}$ & Mean & SD \\
\hline 1 & Academic librarians are exceptionally effective in the performance in their duties & 9 & 2.52 & 0.67 \\
\hline 2 & Academic librarians perform duties moderately & 9 & 2.78 & 0.54 \\
\hline 3 & $\begin{array}{l}\text { Academic Librarians are highly proficient in the practical application of professional/technical } \\
\text { knowledge }\end{array}$ & 9 & 2.64 & 0.44 \\
\hline 4 & Academic librarians get a great deal done with a set of time frame & 9 & 2.67 & 0.68 \\
\hline 5 & Academic librarians perform their duties but not positively outstanding & 9 & 2.51 & 0.49 \\
\hline 6 & Academic librarians perform duties competently & 9 & 2.43 & 0.70 \\
\hline 7 & Academic librarians are definitely ineffective and are not up to the duties & 9 & 2.74 & 0.33 \\
\hline 8 & Academic librarians maintain very high standards; and their work is virtually error proof & 9 & 2.49 & 0.48 \\
\hline 9 & Academic librarians grapple with the problems after they arise & 9 & 2.55 & 0.51 \\
\hline 10 & Academic librarians anticipate problems after they arise & 9 & 2.54 & 0.62 \\
\hline 11 & Academic librarians get straight to the roots of the problem & 9 & 2.66 & 0.48 \\
\hline 12 & Academic librarians seldom see beyond the surface of the problem & 9 & 2.55 & 0.33 \\
\hline 13 & Academic librarians proposal are constantly consistently sound & 9 & 2.56 & 0.47 \\
\hline 14 & Academic librarians are tactless and cannot deal with the public & 9 & 2.60 & 0.59 \\
\hline $15 s$ & $\begin{array}{l}\text { Academiclibrarians are easily thrown off balance, they are not reliable even under normal } \\
\text { circumstances }\end{array}$ & 9 & 2.54 & 0.53 \\
\hline 16 & Academic librarians are deficient in applying professional/technical knowledge of practical issues & 9 & 2.38 & 0.50 \\
\hline 17 & Academic librarians are accurate in the use and interpretation of figures & 9 & 2.69 & 0.32 \\
\hline \multirow[t]{2}{*}{18} & Academic librarians are determined to carry out task through, to the end & 9 & 2.64 & 0.39 \\
\hline & Mean of mean & 9 & 2.60 & 0.29 \\
\hline
\end{tabular}

Table 2 above indicates that the respondents have varying level of opinions on the level of performance of librarians in academic libraries in Benue State of Nigeria. For instance, they agreed that they are exceptionally effective in the performance of their duties, a great deal is done within a set of time frame; get straight to the root of the problem. The librarians are accurate in the use and interpretation of figures and they are determined to carry task through to the end. However, the respondents stated that they grapple with the problem after they arise; seldom see below the surface of the problem and are deficient in applying professional/technicalknowledge to practical issue. They are tactless and cannot deal with the public. This shows that the level of job performance of librarians is low.

Table 3: Mean and SD of Responses on Autocratic Leadership

\begin{tabular}{|c|c|c|c|c|}
\hline S/No & Autocratic Leadership Style & $\mathbf{N}$ & Mean & SD \\
\hline 1 & The librarian manager is often over bearing in his regular inspection of my work & 78 & 2.35 & 0.38 \\
\hline 2 & $\begin{array}{l}\text { The librarian manager doesn't accommodate any kind of domestic excuse interfering with my } \\
\text { duties }\end{array}$ & 78 & 2.49 & 0.44 \\
\hline 3 & $\begin{array}{l}\text { The librarianmanager believe that I will work best in a situation where I am given clear and direct } \\
\text { instruction on my job. }\end{array}$ & 78 & 2.71 & 0.42 \\
\hline 4 & The librarian manager wear an officious look most of the time & 78 & 2.56 & 0.63 \\
\hline 5 & The librarian manager rules with an iron hand & 78 & 2.48 & 0.49 \\
\hline 6 & The librarian manager does not readily accept new ideas & 78 & 2.35 & 0.50 \\
\hline 7 & The librarian manager takes decisions arbitrarily & 78 & 2.43 & 0.56 \\
\hline \multirow[t]{2}{*}{8} & The librarian manager does not explain his actions & 78 & 2.35 & 0.55 \\
\hline & Mean of means & 78 & 2.46 & 0.31 \\
\hline
\end{tabular}

Note: $\mathrm{N}=$ =Number of academic librarians $\mathrm{SD}:=$ Standard Deviation

Sources: Field sources

Table3 above show that the librarians manager are autocratic to an extent. The mean scores of 2.71 shows that the librarians manager believe that the academic librarians will work best in a situation where they are forced to perform their job. The mean scores of 2.56 shows that the librarian managers wear an officious look most of the time. The mean scores of 2.35indicates that the librarian managers are often in their regular inspection of the academic librarians' work. 
The mean scores of 2.43 shows that they take decisions arbitrarily.

The mean of mean scores of 2.48 revealed that the librarian managers rule with an iron hand. From the mean scores of 2.35 the librarianmanager do not readily accept new ideas, and do not explain his actions.

\section{Conclusion and Recommendations}

It can be concluded that the librarian managers in Benue State of Nigeria adopted more of democratic leadership style which is followed by bureaucratic leadership style and autocratic style with laissez-faire leadership style been last. That autocratic leadership style does not significantly influence the job performance of academic librarians and that the level of performance of academic librarians was low.

Based on the above findings, the following recommendations have been presented:

- Librarian managers should be supervised and closely monitored by the higher institutions' management to ensure that the autocratic and laissez-faire ones among them are checked so as to provide conducive climate for theacademic librarians.

- The higher institutions' management should through seminar and work shop encourage strengthen and enhance the use of democratic leadership style in the administration of their libraries in Benue State of Nigeria.

- Private owned higher institutions should endeavour to provide better conditions of services for their librarians. This will in no small measure encourage them to perform their duties more efficiently.

- Librarian managers should be appointed not only on the basis of experience alone but high academic qualifications.

\section{References}

Adamaechi, B.C. and Romaine, H.A. (2002).Issues, Problems and Prospects of Free Compulsory and Qualitative Education in Nigeria. Onitsha: Nigeria Education.

Canadian Association of Student Activity Advisers (2004).Leadership Styles.Retrieved from Info @ cassia-resources Net on June 18, 2014.

Clark, D. (2000). Big Dog's Leadership Page. Leadership Styles. Retrieved From http./www.nwlink-com/-donclark/leader/leadersthtml on July 12, 2014

Eden, D.A. (1998). Introduction to Education Administration In Nigeria. Ibadan: Spectrum Books.

Enoch, A.O. (1999). A handbook of Educational Foundations.Jos: ChallengePress.

Igbo, R.O. (2002). Fundamentals Of school Management.Enugu: Cheston Ltd.

Jones, K. (2006) Conflict and Change in library Organisations: People Power and service London: Clive Bingley.s

Melling, M. and Little, J. (eds) (2004) Building a Successful Customer service Culture. A Guide for Library and Information Managers. London. Facet.

Mgbodile, T. O. (2004). Management Styles for Effective Schools Administration.In T.O.

Mgbodile (ed.)Fundamentals in Educational Administration and Planning.(pp 105 - 116). Enugu: Magnet.

Ngoka, G.N. (2002). Stress Management in Organisations, Universities and Political Circles. Enugu.

Nwankwo, J. (2001). Educational Administration. Theory and Practice, Nigeria: Vikas.

Nworgu, B.G. (2006). Educational Research: Basic Issues and Methodology (2nded.). Nsukka: University Trust.

Pagewise (2002).Styles Of Leadership. Retrieved from http:/l:www-esortment-com/index-htm on April 24, 2014

Ram, C. (2001). What the C E O Wants You to Know: The Little Book of Big Ideas. New York, Ny: Crown ExecutiveAbility; Middle Managers; Success in Business; Corporations - Growth; Industrial Management.

Rhode, P. (1989). Oxford Advanced Learners Dictionary of Current English. Tokoyo: University Press.

Scholl, R.W. (2000). Changing Leadership Style.Retrieved from http://www.cba.uri.edu/schll/Notes/Leadership-Determinants.Html on February 24, 2006.

Akabogu, G.C., Ndu, A. (1992). Developing Quality Improvement Processes in Consulting Engineering Firms.Journal of Management in Engineering. May - June.

Umeakuka, O.A. (2005). Leadership.In O.A. Umeakuka (ed.) Leadership in Physical Education, Recreation, Sports and Dance.(pp 1 12). Nsukka: Great AP Express.

Yalokwu, P.O. (2000). Management concepts and Techniques. Lagos: Peack. 